\title{
THE PERCEIVED IMPACT OF DOWNSIZING AND ORGANISATIONAL TRANSFORMATION ON SURVIVORS
}

\author{
N NDLOVU \\ Department of Human Resource Management \\ Faculty of Management Sciences \\ Mongosuthu Technikon \\ S BRIJBALL PARUMASUR \\ Programme in Human Resource Management \\ School of Management \\ Faculty of Management Studies \\ University of KwaZulu-Natal (Westville Campus)
}

\begin{abstract}
Change is a way of life and the ability to manage change is a key factor in organisational survival and effectiveness. This article evaluates the 'survivor syndrome' and assesses the impact of the process of downsizing and transformation on communication, trust, survivor commitment and loyalty, morale and career advancement opportunities. The study was conducted using a stratified random sample of 361 employees/survivors in a branch of a motor manufacturer that had undergone major transformation. Data was collected using a self-developed questionnaire and analysed using descriptive and inferential statistics. The study generates a framework/model of critical change implementation factors and recommendations that will enable change managers to sense, adjust, respond and implement change timeously so as to gain strategic and competitive advantage.
\end{abstract}

\section{OPSOMMING}

Verandering is 'n lewenswyse en die vermoë om te verander is 'n kernaspek in organisasieverandering en -oorlewing. In hierdie artikel word die 'oorlewingsindroom' beoordeel en word die impak van die afskalingsproses en transformasie op kommunikasie, vertroue, 'oorlewende' toewyding en lojaliteit, moraal en loopbaanvorderingsgeleenthede takseer. Die studie is uitgevoer, met die gebruik van 'n gestratifiseerde ewekansige steekproef van 361 werknemers/'oorlewendes' in 'n afdeling van 'n motorvervaardiger wat ingrypende transformasie ondergaan het. Data is ingesamel by wyse van 'n selfontwikkelde vraelys en ontleed aan die hand van beskrywende en inferensiële statistiek. Die studie het 'n raamwerk/model van kritieke veranderingsimplementeringsfaktore en aanbevelings gegenereer wat veranderingsbestuurders in staat sal stel om die gewaarwording, aanpassing, reaksie en implementering van verandering tydig te doen sodat strategiese en mededingingsvoordeel behaal kan word.

Organisations are operating within a difficult economic environment and in the face of fierce world competition (George \& Jones, 2002). In order to survive and ensure the attainment of organisational goals and profitability, they have to continuously adapt and change to new forms of organisations that are flexible and constantly creating new innovations (Bloise, Cook \& Hunsaker, 2003). Furthermore, organisations are shifting boundaries as new alliances are being created and resources are innovatively being exploited (Vermaak, 2002). This can create uncertainty and anxiety in employees but in "todays global information age the strategy of merely building on present incremental improvements is obsolete" (Vermaak, 2002: 4). The ability to sense, adjust, respond and implement change timeously, is now being recognised as a form of strategic and competitive advantage (Robertson, 2002). Hence, organisational transformation is concerned with strategic change and with moving to a future state, which has been defined generally in terms of strategic vision and scope (Armstrong, 1999).

Continuous change, therefore, has become an inevitable aspect in industry and the ability to manage change is a key factor in organisational survival (Osland, Kolb \& Rubin, 2001). According to Hodgetts (1999), if the overall change process is carefully managed, the new conditions can result in both increased productivity and profit. Since change has the effect of seismic movement that ruffles and offsets conventional comfort zones, strategic repositioning of an organisation is vital (Denton \& Campbell, 1999). Undoubtedly, the central element of a successful organisation lies in the importance of achieving productivity through the effective management of people and their commitment to, and involvement with, the

Requests for copies should be addressed to: brijballs@uk,zn.ac.za organisation (Mullins, 2002). Hence, during the change process, human resources repositioning and people management review is required to ascertain the quality of managers and employees and the current people management style within the organisation.

Changes in organisations are stimulated by multiple internal and external forces, often interacting to reinforce one another (Bloise et al., 2003). Internal forces of change include reorganisation, conflict between organisational components, change in cultural dynamics, whilst external forces of change incorporate technological advancement, changing employee demographics, market changes and competition. Managers' responses to these factors, in turn, often have a significant impact on individuals within the organisation (Bloisi et al., 2003). Change has resulted in the redesign of jobs, the revision of working relationships and a varying perspective of career opportunities, all of which have contributed to massive redundancies and the demise of security of employment for many individuals. Recent organisational transformations have included the redrawing of divisional boundaries, flattening of hierarchic levels, spreading of spans of control, reducing product diversification, revising compensation, streamlining processes, and reforming governance (Bowman, Singh, Useem \& Bhadury, 1999). Hence, organisational transformation comes with significant changes in the organisational structure of the firm, including divisional redesign and employment downsizing (Mullins, 2002). Cameron (1994) defined downsizing as a set of activities undertaken by management, designed to improve organisational efficiency, productivity and competetiveness. It represents a strategy implemented by managers that affects the size of the firm's workforce, costs and the work processes. Robbins (1997) described downsizing as a practice of reducing an organisation's size through extensive layoffs. Organisational downsizing involves abolishing whole 
layers of the organisation and managing with fewer people. Hence, Drummond (2000) believes that the process of downsizing increases the burden upon those who remain, that is, the survivors thereby, placing a premium on commitment. A prolonged period of downsizing creates a climate of intensified work regimes and a breakdown in the traditional career ladder, resulting in commitment based on fear rather than loyalty to the organisation (Newell \& Dopson, 1996).

There are various reasons why employees resist transformation, namely, an individual's predisposition towards change, misunderstanding and fear of the unknown, climate of mistrust, fear of failure, loss of status and job security, peer pressure and group relationships, personality conflicts, poor timing and nonreinforcing rewards, and selective perception and retention (Hodgetts, 1999; Kreitner \& Kinicki, 1999; Marshall, 2000; Swanepoel, Erasmus, van Wyk \& Schenk, 2000; Winkler, 2002; George \& Jones, 2002). The successful charting of organisations throughout major change relies heavily on managing the remaining employees, that is, survivors. The set of shared reactions and behaviours of people who have survived an adverse event has been termed the survivor syndrome. It is increasingly being acknowledged that survivors often experience the effects of major change as deeply as those made redundant. Survivors often show emotions and responses that include shock, disbelief, betrayal, animosity towards management and concern about colleagues, which find expression in decreased motivation, lower morale, guilt and fear about security (Cascio, 1993; Tomasko, 1990; Thornhill, Saunders \& Stead, 1997). According to Cascio (1993), surviving employees become narrow-minded, self absorbed and risk averse. Morale sinks, productivity drops and survivors distrust management (Cascio, 1993). Tomasko (1990) observed other effects, namely, the high human costs, psychological trauma experienced by the victims and survivors, reduced employee commitment, lower performance among employees due to job insecurity, greater loss of valuable employees and lower morale. Thornhill et al. (1997) caution that downsizing is usually not undertaken as part of a broader strategic repositioning of the firm, and some companies risk cutting "muscle instead of fat" and thereby, lose key competencies.

The management of survivors requires an integrated combination of programs encompassing employee involvement techniques, problem solving, team-building activities and counselling about long-term aspirations and career opportunities to address both individual and organisational needs (Cameron, 1994; Sadler, 1995; Greenberg \& Baron, 2000; Mullins, 2002). There is a need for change management, which recognises the individual perspective as the reactions and subsequent behaviours of remaining employees are fundamental to the success of the transformations that are being instituted (Cameron, 1994). An integral part of a successful change process is for managers to recognise that transformation is as much a function of an individual's behaviour as it is of the strategies, structures and systems that top management introduces (Ghoshal \& Bartlett, 1996). This highlights the importance of helping people to process their feelings, of educating them in the new organisational vision and structure, and recognising their career management needs.

Doherty \& Horsted (1995) state that transition management requires the development of human resources strategies which dovetail the use of internal and external interventions. The aim is to give equal support and assistance to the individual's personal transition by offering them opportunities to develop themselves for the benefit of the organisation, whatever that may be in the future (Doherty \& Horsted, 1995). They also suggest the provision of outplacement programmes to redundant employees and succession planning or career management to all other employees.

Survivor syndrome issues can be painful and far reaching at both the individual and organisational levels. Employees often rationally understand and defend the need for downsizing, but find it difficult to accept it emotionally. This highlights the importance of helping people to process their feelings, of educating them in the new organisational vision and structure, and recognising their career management needs.

This study focuses on the impact of transformation on the survivors, that is, the employees that remain after the downsizing exercise. It explores the extent to which survivor morale, commitment, loyalty and trust and perceived career development opportunities are affected by the transformation process.

Objectives of the study

The study aims to:-

- Assess survivors' perceptions of the impact of the process of downsizing and transformation on the key dimensions of the study (communication, trust, employee commitment and loyalty, employee morale and career advancement opportunities) respectively.

- Determine the extent to which the dimensions of the study (communication, trust, employee commitment and loyalty, employee morale and career advancement opportunities), that are influenced by the process of downsizing and transformation, interrelate with each other.

- Evaluate whether the biographical profiles of survivors influences their perceptions of the impact of the process of downsizing and transformation on the key dimensions of the study (communication, trust, employee commitment and loyalty, employee morale and career advancement opportunities) respectively.

\section{METHOD}

\section{Sample}

The study was undertaken in a branch of a successful motor industry, which has a total population of 6000 employees from which a sample of 361 employees was drawn using a probability sampling technique. Stratified random sampling was used to ensure that subgroups within the population, based on job category, are adequately represented in the sample. The researcher divided the population into subgroups or strata according to their job category (top management, middle management, technical, clerical and workforce) and a random sample was taken from each stratum as it was imperative to determine perceptual differences among them.

\section{Measururing instrument}

Data was collected using a self developed questionnaire, specifically designed to capture survivors' cognitive, affective and behavioural responses to a series of downsizing exercises adopted by the organisation. The questionniares comprised of three sections. The first section which focuses on the biographical data of the subjects includes age, highest educational qualification, tenure, job category, race, gender and is measured on a nominal scale. The second section contains questions based on the key dimensions of the study:-

- Employee morale - The assessment of survivor morale is linked to the feeling of guilt at still having a job whilst colleagues were downsized.

- Employee commitment - The assessment of overall employee commitment is linked to the willingness of survivors to identify with the organisational goals and aspirations and to make sacrifices for the organisation as well, after the retrenchment exercise.

- Employee trust and loyalty - This dimension focuses on the extent to which survivors feel a sense of betrayal that the promise of lifelong employment, still implicit in the employer and employee relationship, has been unceremoniously broken. The assessment of this dimension focuses on whether or not survivors become insecure about their jobs after the downsizing exercise.

- Career development opportunities - This dimension focuses on whether remaining employees are given opportunities to achieve their career goals and aspirations. It would then be possible to 
determine whether or not there is a perceived decrease in career development opportunities after the transformation process.

The abovementioned dimensions were measured using a 5 point Likert scale ranging from strongly disagree (1) to strongly agree (5). Section three is an open-ended question that allows the respondents to report anything they would like to say about any of the dimensions of the study relating to the transformation process or managing survivors after the downsizing exercise.

The questionnaires were administered by mail in order to enable respondents to complete it at their own convenience. A rigorous follow-up ensured that 361 successfully completed questionnaires were received which, according to Sekaran's population- to-sample size table, is an adequate composition for a population of 6000 (Sekaran, 2001). The validity of the questionnaire was determined using Factor Analysis. A principal component analysis was used to extract initial factors comprising of 27 items. An iterated principal factor analysis was performed using SPSS with an Orthogonal Varimax Rotation. Five factors with latent roots greater than unity were extracted from the factor loading matrix resulting in 25 items. Only items with loadings $>0.5$ were regarded as being significant. Furthermore, when items were significantly loaded on more than one factor only those with the highest value were selected. The significant loadings are reflected in Table 1.

\section{TABLE 1}

\section{FACTOR ANALYSIS}

\begin{tabular}{lc}
\hline Items that load significantly on each Factor & Component \\
Weighting/ \\
Loading
\end{tabular}

FACTOR 1 - TRUST

I believe that management has been at least honest with bad

and good news about changes in the organisation.

I received adequate information about the transformation

before it was implemented.

Management provides a clear set of direction regarding

recruitment and selection of staff

I received adequate information about the transformation

process during and after it was implemented.

I was very clear about management's intentions when it

came to employee transfers.

Morale increased among employees after the introduction of double shifting in the company.

FACTOR 2 - EMPLOYEE COMMITMENT AND LOYALTY

Despite the process of transformation, employees are willing

to put in extra effort beyond what is normally expect of

them in order to ensure the success of the organisation.

Employees are not willing to put an extra effort to what is

required of them.

Employees are very committed to the organisational goals after the transformation process.

Employees are still committed to the organisational goals after the transformational process.

Employees are willing to own and solve problems rather than to blame others for the problem.

FACTOR 3 - CAREER ADVANCEMENT OPPORTUNITIES

Employees are no longer committed to the organisational goals after the transformation process.

The career advancement opportunities in this company are good.

Due to tranformation, many chances of being promoted

have increased

I am confident I can achieve my personal goals in this company. Promotions in this company are conducted and awarded fairly.

FACTOR 4 - COMMUNICATION

I feel that management has done all they can to help me understand exactly what is expected of me following the changes to the organisation.

Little information about business strategy in this organisation

has created a trust gap between managers and employees.

I believe that communication in this company is generally

honest, open and candid.

There are open channels of communication in this organisation.

Employees trust management after the transformation process.
FACTOR 5 - TRUST

I was fearful that there could be more job losses.

The transformation resulted in some adverse emotions, which prevented employees from getting on with their jobs. Due to the transformation, many chances of being promoted

have decreased.

From Table 1 it is evident that Factors 1 and 5 were generated as relating to trust. In addition, none of the factors had significant loadings on employee morale. This may be attributed to the subjects' difficulty in distinguishing between trust and employee morale. The items in the questionnaire relating to these two factors are perceived by subjects as being the same dimension.

The reliability of the questionnaire was determined using Cronbach's Coefficient Alpha, the value of which was 0.7167 . This alpha coefficient indicates a high level of internal consistency of the items. It also reflects that the questionnaire can reliably measure the impact of the process of downsizing on the key variables of the study.

\section{Statistical analysis}

Data was analysed using both descriptive (measures of central tendency and dispersion) and inferential (correlation, t-test, analysis of variance, multiple regression) statistics. Data from the questionnaires were captured using Excel (Version 5) and processed using Simstat.

\section{RESULTS}

\section{Descriptive Statistics}

Perceived Impact of Process on Downsizing and Transformation The perceived impact of the process of downsizing and transformation on communication, trust, employee commitment and loyalty, employee morale and career advancement opportunities was assessed (Table 2).

TABLE 2

Descriptive Statistics: Perceived impact of Process OF DOWNSIZING AND TRANSFORMATION

\begin{tabular}{lccccc}
\hline Variable & Mean & Std Dev. Maximum Perceived Critical range \\
& & \multicolumn{5}{c}{$\begin{array}{c}\text { Mainable } \\
\text { score }\end{array}$} & $\begin{array}{c}\text { Level of } \\
\text { dissatis- } \\
\text { faction\% }\end{array}$ \\
\hline Communication & 13,06 & 3,71 & 25 & 47,76 & $12,68-13,45$ \\
Trust & 14,85 & 3,10 & 25 & 40,61 & $14,53-15,17$ \\
Employee & 18,35 & 2,59 & 30 & 38,85 & $18,35-18,08$ \\
$\begin{array}{l}\text { Commitment and } \\
\text { Loyalty }\end{array}$ & & & & & \\
Employee Morale & 20,78 & 2,42 & 30 & 30,74 & $20,53-21,03$ \\
Career & 17,64 & 3,84 & 25 & 29,46 & $17,24-18,03$ \\
Advancement & & & & & \\
Opportunities & & & & & \\
\hline
\end{tabular}

Table 2 indicates that the process of downsizing and transformation was perceived by survivors as impacting on the variables of the study in varying degrees. The greatest area of dissatisfaction/impact was with communication $(47,76 \%)$, followed by trust $(40,61 \%)$, commitment and loyalty $(38,85 \%)$, morale $(30.74 \%)$ and then, perceived career advancement opportunities $(29,46 \%)$.

On the dimension of communication, $70 \%$ of the survivors either agreed or strongly agreed that there were no open channels of communication in the organisation during the process of downsizing. Furthermore, $67 \%$ of the survivors strongly disagreed with the statement that communication in the company is honest, open and candid. In addition, $40.1 \%$ of the subjects indicated that they strongly disagree and a further $22,1 \%$ disagree that management has done all they can to help them understand exactly what is expected of them following the changes in the organisation. 
With regards to trust, the analyses revealed that survivors were fearful that there could be more job losses. It also revealed that employees did not receive adequate information about the transformation before, during and after it was implemented. The analyses revealed that $67 \%$ of the survivors do not trust management after the transformation process.

It was found that $48,3 \%$ of the subjects agree and a further $16 \%$ strongly agree that many chances of being promoted have decreased due to transformation. The response to the statement "I am confident I can achieve my personal goals in this company" included disagree $(31,2 \%)$ and strongly disagree $(6,4 \%)$ responses. Hence, $37,6 \%$ of the survivors indicated that they are not confident that they can achieve their personal goals in this company.

The results indicate that $63 \%$ of the survivors agreed and a further $19.1 \%$ strongly agreed that they are still committed to the organisational goals after the transformation process and $82 \%$ indicated that they are willing to exert extra effort to fulfil what is expected of them, even after the transformation process.

\section{Inferential Statistics}

\section{Hypotheses}

Hypothesis 1

There exists significant intercorrelations amongst the key variables of the study that are influenced by the process of downsizing and transformation (communication, trust, employee commitment and loyalty, employee morale and career advancement opportunities) respectively.

Table 3 indicates that whilst no significant relationship exists between survivor commitment and loyalty and perceived career advancement opportunities, the remaining intercorrelations amongst the variables of the study (communication, trust, employee commitment and loyalty, employee morale and career advancement opportunities) are significant at the 5\% level of significance. This implies that the process of downsizing and transformation impacts on these variables in an interconnected manner and has a rippling or snowballing effect thereby having the potential to have a magnanimous impact on the individual employee/survivor.

TABle 3

INTERCORRELATION AMONGST KEY VARIABLES OF THE STUDY

\begin{tabular}{|c|c|c|c|c|c|}
\hline Variables & $\begin{array}{l}\text { Commun- } \\
\text { ication }\end{array}$ & Trust & $\begin{array}{l}\text { Employee } \\
\text { Commit- } \\
\text { ment and } \\
\text { Loyalty }\end{array}$ & $\begin{array}{l}\text { Employee } \\
\text { Morale }\end{array}$ & $\begin{array}{l}\text { Career } \\
\text { Advance- } \\
\text { ment } \\
\text { Oppor- } \\
\text { tunities }\end{array}$ \\
\hline $\begin{array}{l}\text { Communication } \\
\text { Trust }\end{array}$ & $\begin{array}{l}1,00 \\
\text { r } 0,547 \\
\text { p } 0,000^{*}\end{array}$ & 1,00 & & & \\
\hline $\begin{array}{l}\text { Employee } \\
\text { Commitment } \\
\text { and Loyalty }\end{array}$ & $\begin{array}{l}\text { r } 0,459 \\
\text { p } 0,000^{*}\end{array}$ & $\begin{array}{l}\text { r } 0,300 \\
\text { p } 0,000 \text { * }\end{array}$ & 1,00 & & \\
\hline $\begin{array}{l}\text { Employee } \\
\text { Morale }\end{array}$ & $\begin{array}{l}\text { r } 0,104 \\
\text { p } 0,049 *\end{array}$ & $\begin{array}{l}\text { r } 0,189 \\
\text { p } 0,000^{*}\end{array}$ & $\begin{array}{l}\text { r } 0,430 \\
\text { p } 0,000^{*}\end{array}$ & 1,00 & \\
\hline $\begin{array}{l}\text { Career } \\
\text { Advancement } \\
\text { Opportunities }\end{array}$ & $\begin{array}{l}\text { r } 0,119 \\
\text { p } 0,023^{*}\end{array}$ & $\begin{array}{l}\text { r } 0,374 \\
\text { p } 0,000^{*}\end{array}$ & $\begin{array}{l}\mathrm{r}-0,047 \\
\text { p } 0,376\end{array}$ & $\begin{array}{l}\text { r } 0,284 \\
\text { p } 0,000^{*}\end{array}$ & 1,00 \\
\hline
\end{tabular}

Hypothesis 2

There is a significant difference in the perception of survivors varying in biographical data (age, highest educational qualification, tenure, job category, race, gender) regarding the impact of the process of downsizing and transformation on the key variables of the study (communication, trust, employee commitment and loyalty, employee morale and career advancement opportunities) respectively.

Table 4 reflects that:-

- There is a significant difference in the perceptions of survivors differing in biographical data (age and race) regarding the impact of the process of downsizing on all the key variables of the study (communication, trust, employee commitment and loyalty, employee morale and career advancement opportunities). Hence, age and race significantly influences perceptions of the transformation process.

- Educational qualification and job category respectively influences survivor perceptions of the impact of the process of downsizing on all variables except employee morale, where no significant differences were noted.

- Tenure influences survivor perceptions of the impact of the process of downsizing on all variables except trust, where no significant difference was noted.

Table 5 reflects that gender influences survivor perceptions of the impact of the process of downsizing on all variables except trust and career advancement opportunities, where no significant differences were noted.

TABLE 5

T-TEST: DIFFERENCES IN PERCEPTION BASED ON GENDER

\begin{tabular}{lcc}
\hline Variable & $\mathrm{T}$ & $\mathrm{p}$ \\
\hline Communication & 7,145 & $\mathbf{0 , 0 0 0 *}$ \\
Trust & 0,353 & $\mathbf{0 , 7 2 5}$ \\
Employee Commitment and Loyalty & 4,067 & $\mathbf{0 , 0 0 0 *}$ \\
Employee Morale & 4,039 & $\mathbf{0 , 0 0 0 *}$ \\
Career Advancement Opportunities & 1,816 & $\mathbf{0 , 0 7 8}$ \\
\hline
\end{tabular}

$\mathrm{p}<0.05$

Hypothesis 3

The variables of the study (communication, trust, employee commitment and loyalty, employee morale and career advancement opportunities), as perceived by survivors, are significantly affected/ influenced by the process of downsizing and transformation.

Table 6 reflects that the variables of the study (communication, trust, employee commitment and loyalty, employee morale, career advancement opportunities) significantly account for $100 \%$ of the impact of transformation on the survivors. These results indicate that the key dimensions of the study were suitable and valid to determine the impact of transformation on the survivors. The extent to which the factors impact on the survivors is evident in

TABLE 4

ANALYSIS OF VARIANCE - DIFFERENCES IN PERCEPTION BASED ON AGE, EDUCATION, TENURE, JOB CATEGORY AND RACE

\begin{tabular}{|c|c|c|c|c|c|c|c|c|c|c|}
\hline \multirow[t]{2}{*}{ Variable } & \multicolumn{2}{|c|}{ Age } & \multicolumn{2}{|c|}{ Education } & \multicolumn{2}{|c|}{ Tenure } & \multicolumn{2}{|c|}{ Job Category } & \multicolumn{2}{|c|}{ Race } \\
\hline & F & p & $\mathbf{F}$ & p & $\mathbf{F}$ & $\mathbf{p}$ & F & $\mathrm{p}$ & F & $\mathrm{p}$ \\
\hline Communication & 28,353 & $0,000^{*}$ & 23,925 & $0,000^{*}$ & 9,234 & $0,000^{*}$ & 59,771 & $0,000^{*}$ & 27,273 & $0,000^{*}$ \\
\hline Trust & 5,388 & 0,001 * & 22,824 & $0,000^{*}$ & 1,118 & 0,342 & 40,158 & $0,000^{*}$ & 10,534 & $0,000^{*}$ \\
\hline Employee Commitment and Loyalty & 12,456 & $0,000^{*}$ & 4,041 & $0,008^{*}$ & 9,455 & $0,000^{*}$ & 11,322 & $0,000^{*}$ & 20,549 & $0,000^{*}$ \\
\hline Employee Morale & 3,889 & $0,009^{*}$ & 1,720 & 0,162 & 12,590 & $0,000^{*}$ & 2,181 & 0,090 & 19,320 & $0,000^{*}$ \\
\hline Career Advancement Opportunities & 35,500 & $0,000^{*}$ & 20,323 & $0,000^{*}$ & 12,008 & $0,000^{*}$ & 28,464 & $0,000 *$ & 77,591 & 0,000 * \\
\hline
\end{tabular}


the Beta loadings in Table 6. In descending level of impact (based on Beta loadings) of the transformation process on the survivors, these variables are career advancement opportunities $(37,7 \%)$, communication $(36,4 \%)$, trust $(30,4 \%)$, employee commitment and loyalty $(25,4 \%)$ and employee morale $(23,7 \%)$.

TABLE 6

MULTIPLE REGRESSION: IMPACT OF THE PROCESS OF DOWNSIZING ON THE KEY VARIABLES OF THE STUDY

\begin{tabular}{lccccc}
\hline Variable & $\begin{array}{c}\text { Unstandardized } \\
\text { Coefficients }\end{array}$ & \multicolumn{4}{l}{$\begin{array}{l}\text { Standardized } \\
\text { Coefficients }\end{array}$} \\
\hline & B & Std. Error & Beta & T & p \\
\hline $\begin{array}{l}\text { Career } \\
\text { advancement } \\
\text { opportunities }\end{array}$ & 1,000 & 0,000 & 0,377 & $1,75 \mathrm{E}+08$ & 0,000 \\
$\begin{array}{l}\text { Communication } \\
\begin{array}{l}\text { Trust } \\
\text { Employee }\end{array}\end{array}$ & 1,000 & 0,000 & 0,364 & $1,51 \mathrm{E}+08$ & 0,000 \\
$\begin{array}{l}\text { commitment and } \\
\text { loyalty }\end{array}$ & 1,000 & 0,000 & 0,304 & $1,27 \mathrm{E}+08$ & 0,000 \\
$\begin{array}{l}\text { Employee morale } \\
\text { Emplon }\end{array}$ & 1,000 & 0,000 & 0,254 & $1,05 \mathrm{E}+08$ & 0,000 \\
\hline
\end{tabular}

\section{DISCUSSION}

- The relationship between the process of downsizing and transformation and the key variables of the study

\section{- Communication}

This study indicates that the majority of subjects felt that there were no open channels of communication in the organisation. In addition, the study proves that employees have never received adequate information about the transformation before, during and after it was implemented. Similar to the findings of Frazee (1997), this study proves that uncertainties in the work environment after a transformation process, coupled with little information about business strategy, have created a trust gap between managers and employees in many corporations as well as in the organisation where the present study was conducted. Survivors will need information about how they will be affected by the changes, which result from downsizing. The provision of such information will be important for survivors who will now be less concerned about loss of their jobs, but who may remain concerned about the removal of those job attributes, which they found attractive before the change was implemented (Thornhill $\&$ Saunders, 1998).

\section{- Trust}

This study indicates a low level of trust in the company. Survivors in this study were fearful that there could be more job losses. The results obtained by Thomas \& Dunkerley (1999) support the finding in this study that the survivors are faced with stress and are fearful of further redundancies. In addition, the study proves that employees do not trust management after the transformation process. Paige (2001) has observed that survivors feel a sense of betrayal that the promise of lifelong learning and employment, still implicit in the employer and employee relationship, has been unceremoniously broken. Witnessing the painful and often undignified exit of their colleagues, remaining staff members are pressurized to figure out why they were so lucky to escape the retrenchment process. Often the employees remaining after the downsizing exercise feel secretly guilty that they have survived, fearful that they may be next in line. The survivors feel rejected and abandoned by an environment that they have come to think of as home, especially because the promise of lifelong employment, still implicit in the psychological contract, has been unceremoniously broken. Coudron (1996) states that executives from Texaco Trading and Transportation in Denver are grappling with all the painful feelings caused by its downsizing process almost two years ago. These feelings include fear, depression, betrayal, mistrust, pain, guilt, loneliness and job insecurity (Coudron, 1996). Survivors question whether management can be trusted ever again after the transformation. They are not sure if they should continue doing their old jobs or if something new is expected of them. Unfortunately, the level of trust in a company just emerging from the major transformation process is often quite low (Ghoshal \& Bartlett, 1996). Furthermore, autonomous units compete intensely for scarce resources and once loyal employees feel that their implicit contracts with the company have been violated by serial layoffs and cutbacks (Ghoshal \& Bartlett, 1996).

\section{- Employee commitment and loyalty}

This study indicates that survivors are still committed to the organisational goals, even after the transformation process. Coudron (1996) states that employees who survive a downsizing feel anything but relief. Similar to the results of this study, research conducted by Newell \& Dopson (1996) found that a prolonged period of downsizing had created a climate of intensified work regimes and a breakdown in the traditional career ladder, resulting in commitment based on fear rather than loyalty to the organisation. On the contrary, Scase \& Goffee's (1989) research found that it was this breaking of the psychological contract, along with greater work demands and increased accountability, which has created the biggest problem for managers, resulting in a loss of commitment.

Downsizing particularly depresses commitment where survivors had a close personal or working relationship with the victims, and where survivors perceive that the exercise was unfair (Meyer \& Allen, 1997). Downsizing is perceived as unfair if selection for redundancy reflects office politics rather than operational need, or if victims received inadequate redundancy pay and help in finding another job (Meyer \& Allen, 1997). Caulkin (1995) maintains that disappointment with the organisation generally affects the most committed employees. The effects of transformation has resulted in a new breed of employees, who are taking charge of their own destinies (Caulkin, 1995).

Kaye (1998) states that after the dust of downsizing settles, employees who have managed to retain their jobs often find that they feel worse about their work lives than those who were forced out. In the current study, more than one third of the survivors indicated that they were not confident that they could achieve their personal goals in the company. As Westerly (1990) observes, the drivers of downsizing (amongst others, increasing competitiveness and customer responsiveness) require an innovative, flexible and committed workforce, with vision and creativity, not one paralysed by fear.

\section{- Employee morale}

This study indicates that the transformation process resulted in some adverse emotions which prevented survivors from getting on with their jobs. Similar results were obtained by Taylor (1996) who found that downsizing causes emotions within a company that range from bitterness to relief to paranoia. However, according to Kaye (1998), the opposite prevails. Kaye (1998) believes that employees who managed to avoid the waves of downsizing move past the debilitating backwash and learn valuable lessons about the reality of the contemporary employee-employer relationship. Employees have productively adjusted their ideas and plans about their current jobs. Taylor's (1996) study indicates that survivor guilt, low morale and fatigue is a consequence of doing more with less. Furthermore, survivors experience the sadness, anger, mistrust, and psychological separation from their organisation. Since they cannot move beyond those emotions, they feel trapped in jobs that no longer engage their full energy, interest, or talent (Kaye, 1998). This study indicates that employees are willing to try new things even though things are uncertain. Kaye (1998) has researched that survivors network, learn, take on new assignments, assess their capabilities and contribute to their organisations by approaching their current positions with 
motivation and energy after the transformation process.

It is also indicated in the study that survivors perceived that absenteeism among staff increased after the introduction of double shifting in the company. According to Clark and Koonce (1995), in many cases companies that downsized and restructured to become more profitable and efficient have not realised either of those outcomes. Instead, they have experienced tremendous fallout especially in the areas of drastically reduced employee productivity and morale, and largely increased levels of absenteeism, cynicism, and turnover. This is supported by Frazee (1997) who found that of the 1441 Human Resources managers from companies that cut jobs between 1990 and July 1996, 72 percent reported an immediate and negative impact on employee morale. Paige (2001) observed that employees in a post-retrenchment corporate culture experience an erosion of trust, a degeneration of morale and a general feeling of fear and paranoia. There is a sudden loss of colleagues, many of them long standing colleagues, and some of them close friends.

\section{- Career advancement opportunities}

This study indicates that promotions in the particular company are conducted and awarded fairly. The resulting perception of fairness protected and enhanced feelings of trust, despite the inherent tensions and painfulness of the decisions (Ghoshal \& Bartlett, 1996). Downsizing undoubtedly reduces opportunities for career progression (Thornhill \& Saunders, 1998). In this study, it was found that the process of downsizing resulted in survivors being unsure of being able to accomplish their personal goals in the company.

Thomas \& Dunkerley (1999) found that survivors are left demotivated, insecure and lacking commitment from the loss of a traditional career. Many of the problems of survivor syndrome come from breaking of the traditional psychological contract, where managers were promised job security and hierarchical career advancement in return for their loyalty and commitment to the organisation's goals (Brockner, Tyler \& Cooper-Schneider, 1992). Scase \& Goffee (1989) deduced that the main cause of dissatisfaction amongst employees is the promotion gap. This study indicates an affirmative response with regards to career advancement opportunities. It also indicates that due to transformation, many chances of being promoted have decreased. Contrary to these results, research examining the impact of downsizing and delayering on survivors' careers in a privatized utility, found that over $50 \%$ of respondents commented that career prospects had worsened (Ebadan \& Winstanley, 1997). Evidence suggests that enforced downsizing decreases career security. Confidence in the organisation's future appeared to increase, but confidence in the individual's own future decreased (Doherty \& Horsted, 1995).

\section{- Biographical correlates}

- Age

The study indicates that there is a significant difference in the perceptions of survivors varying in age regarding the impact of the process of downsizing and transformation on communication, trust, employee commitment and loyalty, employee morale and career advancement opportunities respectively. These results are in congruence with that of Winkler (2002) who found that younger employees, as well as employees severely affected by the change, want frequent qualitative communication. This further suggests a quest for knowledge and understanding amongst today's workforce.

\section{- Gender}

The study indicates that there is a significant difference in the perceptions of male and female survivors regarding the impact of the process of downsizing and transformation on communication, employee commitment and loyalty and employee morale respectively. However, there is no significant difference in the perceptions of males and females regarding the impact of the process of downsizing and transformation on the level of trust and career advancement opportunities respectively. Phillips \& Imhoff (1997), on the contrary, state that the career experiences and advancement opportunities of women are different from those of men. They state that men advance faster, further and with greater compensation. In addition, Moore (2000) states that gender segregation reflects and breeds inequality. Most female jobs are characterised by low wages, limited access to employee training programmes, and little or no chance for advancement.

More evidence suggests that women are exploited in terms of less pay for harder work, limited career advancement and/or promotion, as well as fewer opportunities for self development and/or training (Frost, 1999).

Clearly with intensified work regimes, longer hours and the break down of formal careers, female managers, who are more likely to have greater domestic responsibilities, are likely to lose out. Research indicates that the demands to work longer hours and the difficulties balancing career and home life, together with the still widespread stereotypes about the need to match styles of management, will have a disproportionate negative impact on women managers (Thomas \& Dunkerley, 1999).

\section{- Education}

This study has revealed that there is a significant difference in the perception of the survivors varying in education levels regarding the impact of the process of downsizing and transformation on communication, trust, employee commitment and loyalty and career advancement opportunities respectively. No significant differences in perceptions exist between survivors differing in education regarding the impact of the process of downsizing and transformation on survivor morale. In support of the present study, research states that highly qualified employees felt that they did not receive adequate information, leading to a sense of powerlessness, and that their psychological contracts had been unilaterally altered by the nature of the changes occurring within their organisations (Thornhill \& Saunders, 1998).

\section{- Tenure}

The present study reveals that there is a significant difference in the perceptions of survivors varying in tenure regarding the impact of the process of downsizing and transformation on communication, employee commitment and loyalty, employee morale and career advancement opportunities respectively. Frost (1999) found that employees with longer service who experience minimal change to their work routine, responded more positively to how adapting employee work behaviour could support successful change implementation. However, in this study there is no significant difference in the perceptions of survivors varying in tenure regarding the impact of the process of downsizing and transformation on trust.

\section{- Job category}

This study shows that significant differences exist in the perceptions of survivors differing in job category regarding the impact of the process of downsizing and transformation on communication, trust, employee commitment and loyalty and career advancement opportunities respectively. Senior executives and employees in the United States tell very different tales about the effects of transformation, according to two surveys released by Brouillard Communications, based in New York City (Michalko, 1995). Seventy eight percent maintained that internal communications before or during a transformation process were handled properly which is in opposition to the study findings. While 59 percent of mid and lower level employees gave their firms good marks for communicating about transformation, 69 percent said that they often did not receive advance information about transformation plans (Michalko, 1995). Studies conducted in North America and the UK have found that work demands increase significantly for middle managers during and after downsizing. Hence, managers have to work harder and longer in order to cope (Thornhill \& Saunders, 1998).

However, in this study it was found that there are no significant 
differences in the perceptions of employees differing in their job category regarding the impact of the process of downsizing and transformation on survivor morale. Thomas \& Dunkerley, 1999) found that downsized, delayered and demoralised, the image of the middle manager is one of low morale, stress and motivated by fear of further redundancies, which are all symptoms collectively termed 'survivor syndrome'.

\section{- Race}

This study indicates that there is a significant difference in the perceptions of survivors differing in race regarding all the dimensions/variables of the study (communication, trust, employee commitment and loyalty, employee morale and career advancement opportunities) respectively. Evidence suggests racists attitude and practices affect trust, morale, motivation, productivity, staff retention and ultimately, profitability. White respondents tend to consistently demonstrate a higher degree of agreement than Black respondents regarding the presence of career advancement opportunities within their organisations (Oakley-Smith \& Winter, 2001).

- Recommendations based on the impact of downsizing/ transformation on the key dimensions of the study The study indicates that the process of downsizing and transformation had the greatest impact on career advancement opportunities, indicating that after the downsizing and the transformation process management has to ensure that the survivors are given the chance for development. Further emphasis is placed on communication, indicating that survivors need to be informed of all the developments in the organisation after downsizing. This will then impact more on the level of trust survivors show towards the organisation. If employees trust the organisation, then it results in a high level of commitment and loyalty, indicating the level of sacrifice the survivors will show after the process. All of the above dimensions, if improved, will obviously increase the level of morale of survivors. The above results have enabled the generation of a model, which provides guidelines for the effective management of the process of downsizing and transformation (Figure 1). Figure 1 reflects that survivors of the process of downsizing will adjust better if greater attention is given to career advancement and effective communication. The diagram reflects the areas of impact of the process of downsizing from point 1 to 5 in descending level of impact as one moves outward from 1 to 5 . Recommendations for the effective management of the change process (in terms of the key dimensions of the study) are presented.

The analysis has proven that downsizing not only affects the workers who lose their jobs but even the survivors. The Human Resources department can help survivors by:-

- Providing emotional support

- Role clarification

- and career management assistance (Coudron, 1996).

To be able to manage survivors after the downsizing process, it is wise to lead by vision and values and not by commands. It is more important for management to help survivors to focus on a larger vision of what is needed, emphasizing the strategies and values that will help make the vision attainable. Managers should meet regularly with survivors to map goals and to seek ideas on how they can work together to meet the goals.

\section{- Recommendations for future research}

The study sample should be expanded to include more branches in the region in order to investigate if the five dimensions that impact of the survivors as a result of downsizing and transformation are also applicable to the organisation as a whole and within the motor industry.

The study should also be extended to include the merger and 'company takeover' syndrome in order to determine the prevalence of these within the organisation and to ensure that these are addressed appropriately.

Downsizing/transformation has a number of effects in the working environment, such as, high turnover, low productivity, high

\section{FIGURE 1: GUIDELINES FOR THE EFFECTIVE MANAGEMENT OF} DOWNSIZING/TRANSFORMATION

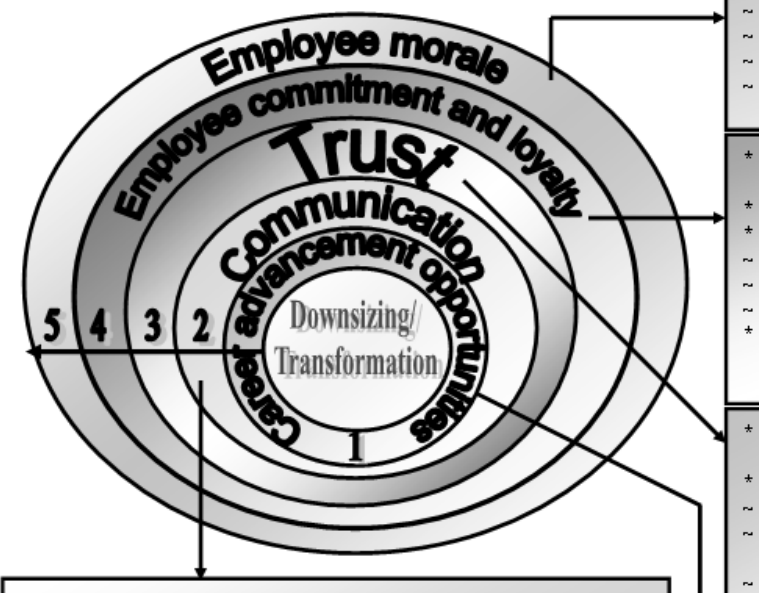

Increase morale by empowering emplo yees through consultation \& me aningful participation - they would be more likely to 'own' results. Numerous strategies may be adop ted to increase survivor morale:Stress collaboration among survivors, not competition. Be honest as to why the downsizing occurred. Tell survivors how they can help the company survive the restructuring. Train survivors in stress awareness, attitude adjustment and time mng. Hold focus gro ups for employees to help the m feel part of what is happening and to allow the m to make suggestions.

Involve people early on so that they have a be ther understanding of what is expected of them.

Put the interests of e mployees first (start with what they want \& need). Let employees particip ate in decisions regarding:their workloads and work environment.

shaping the criteria of who will go and who will stay.

how survivors can work together in a leaner organisation.

Involving emp loyees in decisions will demonstrate that even when times are rough, manage ment has their best interests and the company's in mind. This will increase commitment and lo yalty.

After a transformation process, manage ment should recognise and reward performance that makes a differe nce.

Strategies to be adop ted include:

Thank each survivor personally for his/her hard work.

Conduct morning chat sessions to update survivors on status of projec ts and highlight desired performance by te am me mbers.

Hold weekly te am lunches so emplo yees can share with co-workers/managers their ide as on how things are going.

Write about emplo yee's accomplishments - company newsletter.

Circulate comp any-wide bulletins of outstanding results.

Institute and enc ourage an open-door policy from lower-level employees to people at the top.

people at the top.
Manage ment must tre at survivors with trust and respect.

Trust requires people to believe in the compe tence of colleagues and their leaders to achieve new stretch targets.

Involve ment is a prerequisite to trust (Ghoshall \& Bartlett, 1996).

Whilst downsizing reduces opporturities for c areer progression, mugt. should reduce the promotiongap.

Quickly stabilise career insecurity \& build confidence in the survivor

regarding his/her own future.

Train survivors for new duties. One cannot perform new duties without instruction.

Figure 1: Guidelines for the effective management of downsizing/transformation 
wastage, role ambiguity, absenteeism and low motivation. Future studies may assess the significance of the aforementioned correlates.

\section{CONCLUSION}

This study, as well as others examining the impact of corporate transformation and downsizing on survivors, contradict the common-sense assumptions that survivors of this process would be relieved, flattered and motivated. Evidently, transformation is a complex and challenging process for an organisation to undertake. It is a process that should not be taken lightly but should be clearly thought through by the leadership of the organisation and the rationale for change must be clearly understood by all participants. The task of managing survivors would not be difficult if the leadership recognises that survivors have special needs, provides the emotional support they deserve and ensure continuous and honest communication.

\section{REFERENCES}

Armstrong, M. (1999). A handbook of human resources management practice. $7^{\text {th }}$ Edition. Norfolk: Kogan Page.

Baghai, M., Coley, S. \& White, D. (2000). The alchemy of growth: Kickstarting and sustaining growth in you company. United States of America: McKinsey \& Co Inc.

Bloisi, W., Cook, C.W. \& Hunsaker, P.L. (2003). Management and organisational behaviour. London: McGraw-Hill.

Bowman, E.H., Singh, H., Useem, M. \& Bhadury, R. (1999). When does restructuring improve economic performance? California Management Review, 41 (2), 33 - 52.

Brockner, J., Tyler, T.R. \& Cooper-Schneider, R. (1992). The influence of prior commitment to an institution on reactions to perceived unfairness: The Higher they are, the Harder they fall. Administrative Science Quarterley, 37 (22), $241-261$.

Cameron, K. (1994). Strategies for successful organisational downsizing. Human Resources Management, 33 (21), 189 - 211.

Cascio, W. (1993). Downsizing? What do we know? What have we learned? Academy of Management, 7(9), 51 - 54.

Caulkin, S. (1995). The new avengers. Management Today, 43(12), $48-52$.

Clark, J. \& Koonce, R. (1995). Engaging organisational survivors. Training and Development, 49 (24), 23 - 30.

Coudron, S. (1996). Teach downsizing survivors how to thrive. Personnel Journal, 75 (1), $38-45$.

Denton, M. \& Campbell, K. (1999). Strategic repositioning - the fundamentals. South Africa: Strong message publications.

Doherty, N. \& Horsted, J. (1995). Helping survivors to stay on board. People Management, 1 (1), 20 - 26.

Drummond, H. (2000). Introduction to organisational behaviour. New York: Oxford University Press.

Ebadan, G. \& Winstanley, D. (1997). Downsizing, delayering and careers - The survivor's perspective. Human Resources Management Journal, 7 (1), 79 - 90.

Frazee, V. (1997). Morale is an issue at home and abroad. Workforce, 76 (7), $16-18$.

Frost, A. (1999). After the rain. Randburg: Knowledge Resources.

Georger, M.J. \& Jones, G.R. (2002). Organisational behaviour. $3^{\text {rd }}$ Edition. New Jersey: Prentice Hall.

Ghoshal, S. \& Bartlett, C.A. (1996). Rebuilding behavioral context: A blueprint for corporate renewal. Sloan Management Review, 37 (22) 23 - 35.
Greenberg, J. \& Baron, R.A. (2000). Behavior in organisations: understanding and managing the human side of work. $7^{\text {th }}$ Edition. New Jersey: Prentice Hall.

Hodgetts, R.M. (1999). Modern human relations at work. $7^{\text {th }}$ Edition. New York: Harcourt Brace College Publishers.

Kaye, B.L. (1998). The Kept-On-Workforce. Training and Development, 52 (10), $32-38$.

Kreitner, R. \& Kinicki, A. (1998). Organisational behavior. $4^{\text {th }}$ Edition. United States of America: McGraw-Hill.

Marshall, E.M. (2000). Building trust at the speed of change. New York: AMACOM.

Meyer, J.P. \& Allen, N.J. (1997). Commitment in the workplace: Theory, research and application. London: Sage Company.

Michalko, M.R. (1995). The effects of restructuring. Training and Development, 49 (6), 1 - 2 .

Moore, D.P. (2000). CareerPreneurs. California: Davies-Black Publishers.

Mullins, L.J. (2002). Management and organisational behaviour. $6^{\text {th }}$ Edition. New York: Prentice Hall.

Newell, H. \& Dopson, S. (1996). Muddle in the middle: Organisational restructuring and middle management careers. Personnel Review, 25 (4), $4-20$.

Oakley-Smith, T. \& Winter, V. (2001). Workplace racism. People Dynamics, 18 (8), $19-21$.

Osland, J.S., Kolb, D.A. \& Rubin, I.M. (2001). Organisational behaviour: An experiential approach. $7^{\text {th }}$ Edition. New York: Prentice Hall.

Paige, V. (2001). Preparing employees for retirement. People Dynamics, 19 (4), 14 - 17.

Phillips, S.D. \& Imhoff, A.R. (1997). Women and career development: A decade of research. Annual Review of Psychology, 48 (32), 31 - 59.

Robbins, S.P. (1997). Managing today. New Jersey: Prentice Hall.

Robertson, A. (2002). Optimising for human performance. People Dynamics, 20 (3), 12 - 15.

Sadler, P. (1995). Managing change. England: Kogan Page.

Scase, R. \& Goffee, R. (1989). Reluctant managers. London: Urwin Hyman.

Sekaran, U. (2001). Research methods for business. $2^{\text {nd }}$ Edition. United States of America: John Wiley \& Sons, Inc.

Swanepoel, B.J., Erasmus, B., van Wyk, M. \& Schenk, H. (2000). South African human resources management: Theory and practice. $2^{\text {nd }}$ Edition. Cape Town: Juta \& Company, Ltd.

Taylor, R. (1996). Corporations should offer more attention to downsizing survivors. Corporate Board, 17(100), 20 - 30.

Thomas, R. \& Dunkerley, D. (1999). Careering downwards? Middle managers experience in the downsized organisation. British Journal of Management, 10 (2), 157 - 169.

Thornhill, A. \& Saunders, M.N.K. (1998). The meanings, consequences and implications of the management of downsizing and redundancy: A review. Personnel Review, 24 (4), $271-296$.

Thornhill, A., Saunders, N.K. \& Stead, J. (1997). Downsizing, delayering - But where's the commitment? Personnel Review, 26 (2), $81-98$.

Tomasko, R. (1990). Downsizing: Reshaping the corporation of the future. New York: AMACOM.

Vermaak, A. (2002). Back to the future. People Dynamics, 20 (3), $4-5$.

Westerly, F. (1990). Middle management and strategy: Microdynamics of inclusion. Strategic Management Journal, 23 (11), $337-351$.

Winkler, N. (2002). Ringing the changes. People Dynamics, 20 (3), 16 - 19. 